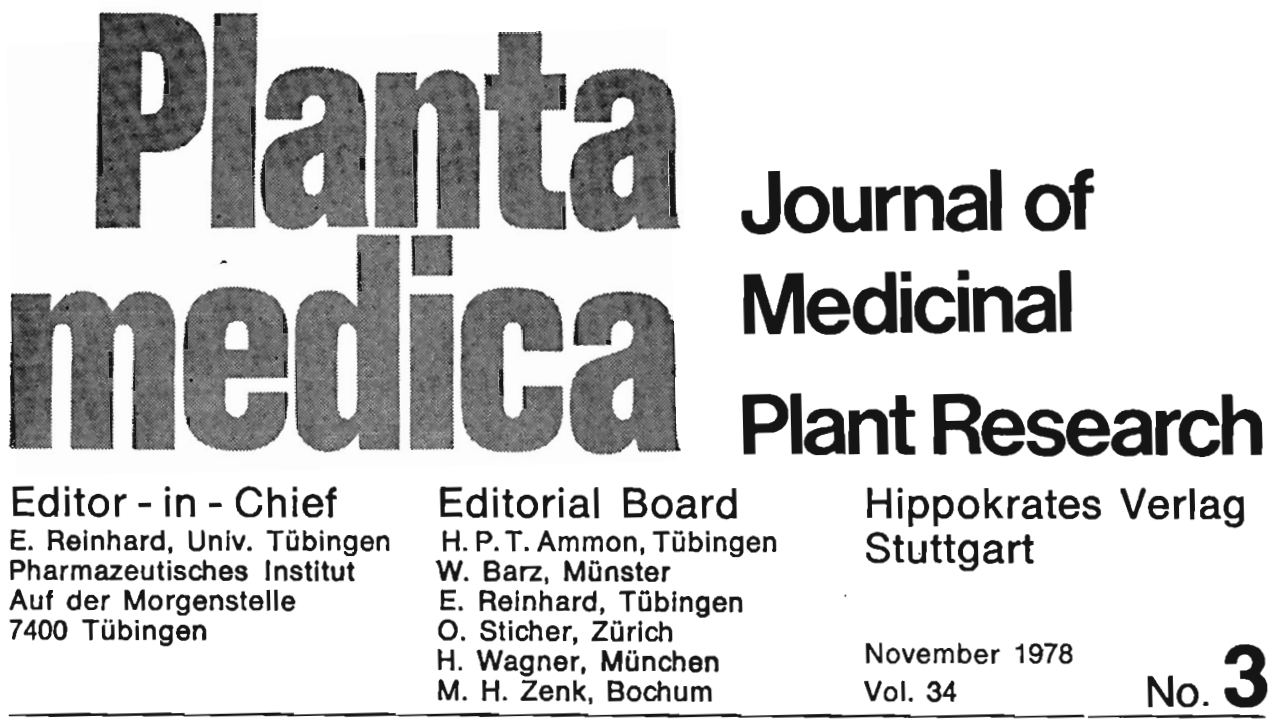

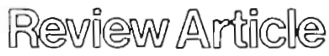

\title{
On the Mechanism of Action of the Cytostatic Drug Anguidine and of the Immunosuppressive Agent Ovalicin, two Sesquiterpenes from Fungi'
}

Guido R. Hartmann, Hartmut Richter, Erika M. Weiner and Wolfgang Zimmermann

Institut für Biochemie der Ludwig-Maximilians-Universität München, Bundesrepublik Deutschland.

Key Word Index: Anguidine; Verrucarin; Ovalicin; Fungal Sesquiterpenes; Lymphocytes; DNA Synthesis, Protein Synthesis.

\section{Abstract}

The sesquiterpene betainyl-anguidine and the structurally related verrucarin

1 Dedicated to Professor Adolf Butenandt on the occasion of his 75 th birthday.
$A$ at the low concentration of $10^{-8} \mathrm{~mol} / \mathrm{l}$ inhibit protein synthesis in lymphocytes from mouse spleen rapidly after addition to the cell culture. DNA synthesis is blocked at similarly low concentrations whereas RNA synthesis is much 
less reduced. The following observations support the notion that DNA synthesis is blocked via inhibition of protein synthesis: (i) DNA synthesis in a cell-free system is not reduced by the drug; (ii) in cell culture protein synthesis is inhibited more rapidly and at lower concentrations than DNA synthesis; (iii) inhibitors of protein synthesis such as cycloheximide or puromycin are similar to betainyl-anguidine in their action on lymphocytes whereas specific inhibitors of DNA synthesis such as cytosine arabinoside or hydroxyurea only partially reduce protein synthesis in lymphocytes.

The sesquiterpene ovalicin at a concentration of $10^{-10} \mathrm{~mol} / \mathrm{l}$ acts as a very potent inhibitor of DNA synthesis in proliferating lymphocytes and in lymphoma cells. RNA and protein synthesis are only weakly affected. The following observations support the conclusion that DNA synthesis is blocked only indirectly: (i) DNA synthesis in a cell-free system is not reduced by ovalicin; (ii) a cell-free system for DNA synthesis prepared from ovalicin-treated lymphocytes shows an impaired synthetic activity; (iii) in cell culture the action of ovalicin is not immediate and requires a $8-15$ hour period of incubation.

\section{Introduction}

Fungi produce a large number of chemical compounds which are highly toxic either for bacteria or for animals and plants. They are toxic because they inhibit biochemical reactions essential for sustaining life. Their unusual speci- ficity for either animals and plants or bacteria is based on fundamental differences existing between molecular constituents of the prokaryotic and eukaryotic cell. If the receptor for the target of such a toxic compound occurs only in a eukaryotic cell exclusively this type of cell will be affected. The specificity of action is particularly pronounced if such a compound possesses a very high affinity for its target. Then very small concentrations are sufficient for the inhibitory action to be observed. If higher concentrations $\left(10^{-6}-10^{-3}\right.$ $\mathrm{mol} / \mathrm{l}$ ) are required the high specificity of action may be lost because weak forces such as hydrophobic interactions may provoke unspecific binding of these compounds also to other cellular constituents with concomitant impairment of their biological functions. Therefore compounds which elicit biological effects at very low concentration command higher interest.

In recent years the effort to suppress the uncontrolled growth of tumor cells and other rapidly proliferating cells such as committed lymphocytes has stimulated a general interest in compounds which act cytostatic for eukaryotic cells.

In this report the mode of action of two different compounds will be discussed which exhibit a high cytostatic activity at very low concentration and act exclusively against eukaryotic cells. Chemically both compounds are distantly related since they possess the basic structure of a sesquiterpene.

\section{Anguidine and related compounds}

Anguidine is produced by various species of Fusaria and shows mycotoxic 


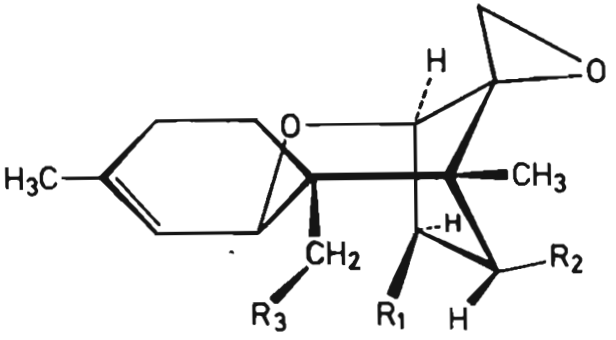

anguidine:

trichothec-9-ene-3,4,15-triol,12,13-epoxy, 4,15-diacetate, $(3 \alpha, 4 \beta)$ :

$\mathrm{R}_{1}=\mathrm{OH} ; \mathrm{R}_{2}=\mathrm{R}_{3}=\stackrel{\mathrm{O}}{\|} \mathrm{C}-\mathrm{CH}_{3}$

betainyl-anguidine (chloride):

$\stackrel{\mathrm{O}}{\|} \underset{\mathrm{C}}{\stackrel{+}{\mathrm{C}}-\mathrm{Cl}_{2}-\mathrm{N}\left(\mathrm{CH}_{3}\right)_{3}} ; \mathrm{R}_{2}=\mathrm{R}_{3}=\mathrm{O}-\mathrm{I}-\mathrm{CH}_{3}$ verrucarin $A$ :

$\mathrm{R}_{1}=\mathrm{H} ; \mathrm{R}_{2}, \mathrm{R}_{3}=$ dicarbonic acid ester of :

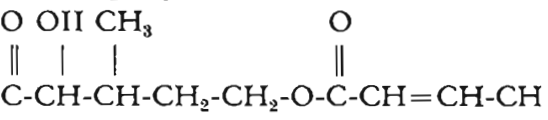<smiles>C=CC(=O)O</smiles>

activity. Chemically it is closely related with the group of verrucarins [1]. Cytostatic activity of anguidine is observed at a concentration of $0.5 \times 10^{-8}$ $\mathrm{mol} / \mathrm{l}$ in mouse mastocytoma cells as well as in human tumor cells (KB cells). At a similarly low concentration the propagation of the DNA containing vaccinia virus and its cyptopathogenic effect is suppressed [2]. With respect to the molecular target of anguidine it has been observed previously that protein synthesis in a cell culture is inhibited at a concentration of $3 \times 10^{-7} \mathrm{~mol} / 1$ in eukaryotic cells such as rabbit reticulocytes or mouse mastocytoma cells. At the same concentration, however, DNA synthesis is equally blocked [2]. Synthesis of proteins and of DNA is achieved by biochemically very different processes. Therefore the question arises if anguidine acts on such unlike biosynthetic pathways by two different independent modes of action. This ist not a far-fetched question. For example, it has been observed that the antibiotic rifampicin specifically blocks RNA synthesis in bacteria [3]. On the other hand it inhibits the multiplication of vaccinia virus in cell cultures by a completely different mechanism [4]. The simultaneous inhibition of two different biochemical reactions, however, may also be explained without the assumption of two different modes of action if both reactions are tightly coupled in vivo.

In view of the observed possibly immunosuppressive activity [2] we have studied the molecular mode of action of anguidine in spleen lymphocytes from mice. In the absence of an antigenic or mitogenic stimulus lymphocytes are metabolically very inactive. Lymphocytes may be induced to proliferate by mitogens such as concanavalin $\mathrm{A}$ as is indicated by a strongly increased synthesis of RNA and proteins followed by a rapid synthesis of DNA after $25 \mathrm{~h}$ of incubation. In most of our experiments we have used the chemically modified derivative betainyl-anguidine which exhibits the same biological effects as anguidine but is much better soluble in water. If betainyl-anguidine is added simultaneously with mitogen and radioactively labelled leucine to lymphocytes in cell culture the incorporation of the radioactively labelled amino acid into proteins, determined after a $20 \mathrm{~h}$ incubation period, is reduced by more than the half in the presence of only $1 \times 10^{-8} \mathrm{~mol} / 1$ inhibitor. 


\section{Table I}

Inhibition of protein synthesis in lymphocytes by betainyl-anguidine or verrucarin $A$.

$2 \mu \mathrm{g}$ concanavalin $\mathrm{A}, 10 \mathrm{nmol}$ mercaptoethanol, $5 \mu \mathrm{Ci}\left({ }^{3} \mathrm{H}\right)$ leucine (resulting specific radioactivity in the medium $13 \mathrm{Ci} / \mathrm{mol}$ ) and inhibitor (as indicated) were added to $10^{6} \mathrm{~B} 6 \mathrm{D} 2$ mouse lymphocytes from spleen (preincubated at $37^{\circ} \mathrm{C}$ for 10-20 h) in Eagle's MEM containing $5 \%$ fetal calf serum (38) (total volume $1.0 \mathrm{ml}$ ). After incubation for $20 \mathrm{~h}$ at $37^{\circ} \mathrm{C}$ incorporation of radioactive label into acid insoluble material was determined (39) (control in the absence of betainyl-anguidine: $4731 \pm 149$ counts $\times \min ^{-1}$; control in the absence of verrucarin A: $8531 \pm 914$ counts $X$ $\left.\min ^{-1}\right)$.

\begin{tabular}{lll}
\hline inhibitor & concentration & $\begin{array}{l}\text { inhibition of protein } \\
\text { synthesis in cell culture }(\%)\end{array}$ \\
\hline betainylanguidine & $4 \times 10^{-9}$ & 20 \\
& $1 \times 10^{-8}$ & 79 \\
verrucarin A & $4 \times 10^{-9}$ & 30 \\
& $1 \times 10^{-8}$ & 83 \\
\hline
\end{tabular}

\section{Table II}

Influence of the cell cycle on the inhibitory action of verrucarin $A$.

The experiments were performed essentially as described in table I except that $2 \times 10^{-8} \mathrm{~mol} / \mathrm{l}$ verrucarin $\mathrm{A}$ and $\left({ }^{3} \mathrm{H}\right)$ leucine were added to the cultures at the time indicated after addition of concanavalin A.

\begin{tabular}{llll}
\hline $\begin{array}{l}\text { verrucarin A } \\
\text { added at } \\
\text { (h) }\end{array}$ & $\begin{array}{l}\text { pulse of } \\
{[3 \mathrm{H}] \text { leucine }} \\
\text { (h) }\end{array}$ & $\begin{array}{l}\text { incorporation } \\
(\mathrm{cpm})\end{array}$ & $\begin{array}{l}\text { incorporation } \\
\text { in absence of drug } \\
(\mathrm{cpm})\end{array}$ \\
\hline 7. & $8-10$ & 69 & 412 \\
15. & $16-18$ & 81 & 1079 \\
39. & $40-42$ & 45 & 447 \\
\hline
\end{tabular}

The same effect is observed with verrucarin $A$, a compound closely related to anguidine (table I). Cellular protein synthesis is blocked rather rapidly. Incubation for only $3 \mathrm{~h}$ with $2 \times 10^{-8}$ $\mathrm{mol} / \mathrm{l}$ verrucarin $A$ is sufficient for a very strong inhibitory effect to be observed. This is observed no matter whether toxin is added 7,15 on 39 hours after the mitogen (table II). To determine whether the synthesis of all cellular proteins is reduced to the same extent the following experiment was performed: $2 \times 10^{-8} \mathrm{~mol} / 1$ inhibitor was added to stimulated lymphocytes which was followed by radioactively labelled methionine one hour later. After two more hours the cellular proteins were separated by polyacrylamide gel electrophoresis in presence of dodecylsulfate. Except for a single protein zone migrating with the relative electrophoretic mobility of 0.52 the synthesis of all other radioactively labelled proteins is uniformly reduced (Fig 1). This is also true for the biosynthesis of histones as will be discussed 


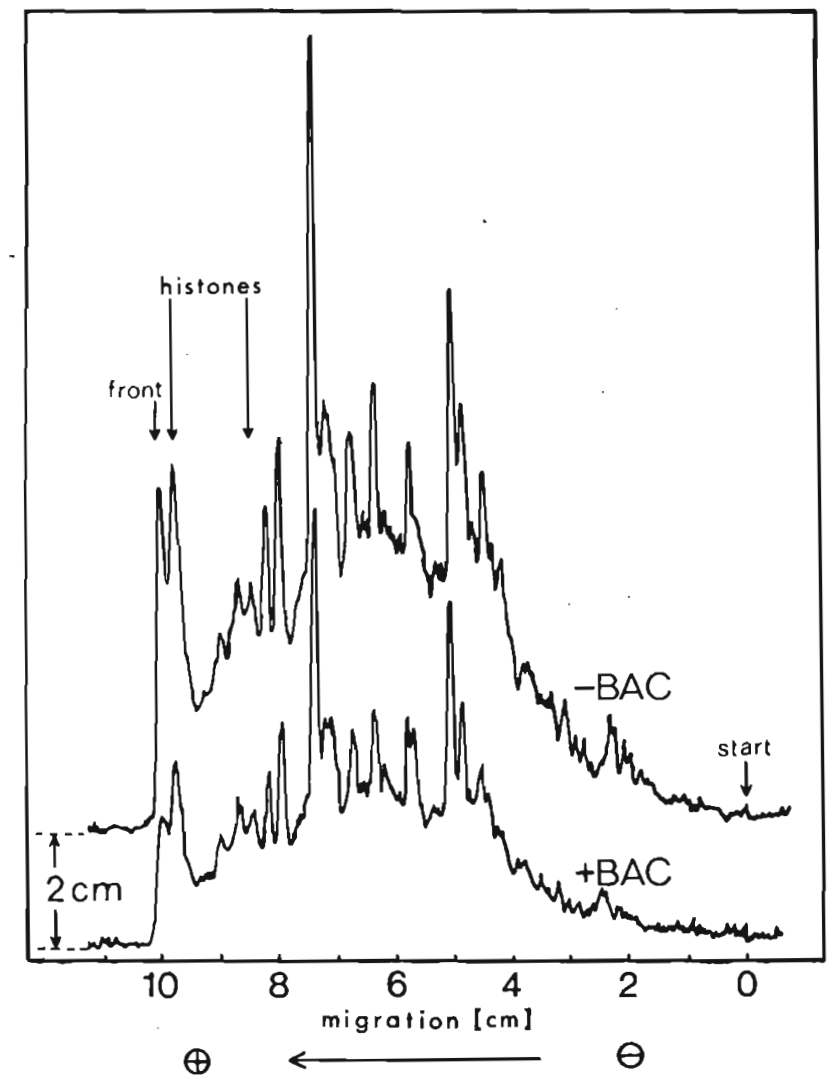

Fig. 1. Gel-electrophoretic analysis of radioactive proteins synthesized during incubation of stimulated lymphocytes with $\left.{ }^{35} \mathrm{~S}\right)$ methionine in the presence or absence of betainyl-anguidine.

$5 \times 10^{7}$ lymphocytes stimulated as described in table III, were incubated for $39 \mathrm{~h}$ at $37^{\circ} \mathrm{C} .1 \mathrm{~h}$ after addition of $2 \times 10^{-8} \mathrm{M}$ betainyl-anguidine (BAC) $0.25 \mathrm{mCi}{ }^{35} \mathrm{~S}$ ) methionine (specific radioactivity $20 \mathrm{Ci} / \mathrm{mol}$ ) were added and the incubation continued for $2 \mathrm{~h}$. Subsequently the cells from $4.5 \mathrm{ml}$ of the incubation mixture were isolated by centrifugation. After washing with cold $0.85 \% \mathrm{NaCl}$ half of the cells were lysed for $10 \mathrm{~min}$ at room temperature by suspending them in about two volumes $60 \mathrm{mM}$ tris- $\mathrm{HCl} \mathrm{pH} 6.8$ containing $10 \%$ glycerol and $2.7 \%$ dodecylsulfate (total volume $50 \mu \mathrm{l}$ ). $20 \mu \mathrm{l}$ of this mixture (equivalent to $10^{6}$ cells) were applied to a slab gel containing a linear gradient of $5-15 \%$ acrylamide with $0.1 \%$ dodecylsulfate. Electrophoresis was carried out at $60 \mathrm{~V}$ overnight [43]. Autoradiography was performed with the dried slab gel for 6 days. The developed film was scanned with a densitometer.

below. Histones are proteins tightly associated with DNA in eukaryotic cells.

These observations support the conclusion that in lymphocytes anguidine and related compounds act in general at very low concentration on protein synthesis. Furthermore, the action of anguidine and its derivatives is not restricted to a certain type of cell such as lymphocytes or to a certain species of animal as follows from experiments with rabbit reticulocytes [5] and HeLa cells [6]. Since they are effective at 
lower concentrations than other inhibitors of protein synthesis such as puromycin or cycloheximide (table VI and VIII and unpublished experiments) their general application in biochemical and biological experiments is suggested.

On the other hand, derivatives of anguidine also act as very potent inhibitors of DNA synthesis as is shown by the following experiment: inhibitor is added together with mitogen to a cell culture of stimulated lymphocytes.
When DNA synthesis is determined by incubation with radioactively labelled thymidine a $50 \%$ inhibition is observed in the presence of only $0.7 \times 10^{-8} \mathrm{~mol} / 1$ of the drug, similar to the inhibition of protein synthesis. Doubling of the concentration of the inhibitor leads to a complete inhibition. Verrucarin A is even more active. DNA synthesis is inhibited at a 10 fold lower concentration than protein synthesis (table III). Obviously anguidine is a very potent

\section{Table III}

Inbibition of DNA synthesis in lymphocytes by betainyl-anguidine, verrucarin $A$ or ovalicin studied in cell culture and in a cell-free system.

$100 \mu \mathrm{g}$ concanavalin A, $0.5 \mu \mathrm{mol}$ mercaptoethanol and betainyl-anguidine were added to $5 \times 10^{7}$ lymphocytes in medium (see table I) (total volume $45 \mathrm{ml}$ ). After $38 \mathrm{~h}$ incubation at $37^{\circ} \mathrm{C} 0.9 \mathrm{ml}$ aliquots of the cell suspension were transferred to test tubes containing $1 \mu \mathrm{Ci}\left({ }^{3} \mathrm{H}\right)$ thymidine (specific radioactivity $6.7 \mathrm{Ci} / \mathrm{mmol}$ ). Incorporation of radioactive label into acid insoluble material was determined after $8 \mathrm{~h}$ incubation at $37^{\circ} \mathrm{C}$. Control without betainyl-anguidine: $26817 \pm 1351$ counts $X \min ^{-1}$. The experiments with verrucarin $\mathrm{A}$ in cell culture were performed essentially as described in table I except that $\left({ }^{3} \mathrm{H}\right)$ leucine was omitted. After $36 \mathrm{~h}$ incubation $0.1 \mathrm{ml}$ medium containing $1 \mu \mathrm{Ci}\left({ }^{3} \mathrm{H}\right)$ thymidine (specific radioactivity $2 \mathrm{Ci} / \mathrm{mmol}$ ) and $10 \mathrm{nmol}$ mercaptoethanol was added. $18 \mathrm{~h}$ later incubation was terminated. Control wihout verrucarin A: 9016 \pm 1784 counts $\times \min ^{-1}$. Experiments with ovalicin in cell culture: $1 \mu \mathrm{g}$ concanavalin A and inhibitor was added to $10^{8}$ lymphocytes preincubated for $12 \mathrm{~h}$. After $38 \mathrm{~h} 1 \mu \mathrm{Ci}\left({ }^{3} \mathrm{H}\right)$ thymidine (specific radioactivity $6.7 \mathrm{Ci} / \mathrm{mmol}$ ) was added and incubation continued for $3 \mathrm{~h}$. Control without ovalicin: $61843 \pm 2313$ counts $X \mathrm{~min}^{-1}$. Synthesis of DNA in a cell-free system was measured essentially as described [7]. Nuclei were from lymphocytes stimulated for $46 \mathrm{~h}$ with concanavalin $\mathrm{A}$ in presence of $10 \mu \mathrm{M}$ mercaptoethanol in the experiment with betainyl-anguidine (as in table I). In the experiment with ovalicin mercaptoethanol was left out. Incubation of the cell-free system was $45 \mathrm{~min}$ at $37^{\circ} \mathrm{C}$. Control without betainylanguidine: 1890 counts $\times \min ^{-1} \times 10^{-8}$ nuclei; control without ovalicin: 436 counts $\times \min ^{-1} \times 10^{-6}$ nuclei.

inhibitor

concentration of drug

inhibition of DNA synthesis (\%)

(M)

in cell culture

in a cell-free system

betainyl-anguidine

$4 \times 10^{-9}$

$1 \times 10^{-8}$

$2 \times 10^{-6}$

verrucarin $A$

$4 \times 10^{-9}$

$1 \times 10^{-9}$

ovalicin

$\begin{array}{ll}2 \times 10^{-10} & 50 \\ 4 \times 10^{-10} & 73 \\ 3 \times 10^{-6} & 75\end{array}$

\section{$-$}

7

\section{$-$}

$-$

$-$ 
inhibitor of the synthesis of proteins as well as of DNA in lymphocytes. This fact has to be taken into consideration when discussing the molecular mode of action of this drug. In the case of verrucarin A DNA synthesis is even more sensitive than protein synthesis. Consequently we have to investigate the question if anguidine derivatives are double-headed inhibitors or if they block a process common to both protein and DNA synthesis.

Such a process would be the production of energy in the form of ATP required for both biosynthetic reactions. However this is not the case as is shown by the following argument. Biosynthesis of RNA also requires energy in the form of ATP. However, RNA synthesis in lymphocytes is much less reduced by a concentration of the inhibitor which inhibits protein synthesis distinctly wit- hin $3 \mathrm{~h}$. Even 100 fold higher concentrations of the drug reduce RNA synthesis by only $50 \%$ (table IV). Such a relatively weak effect on RNA synthesis has been previously observed in mouse mastocytoma cells [2]. Of course, there are many other biochemical pathways which precede both DNA and protein synthesis. Any of them could be the target of anguidine. Instead of discussing them separately we would like to mention several arguments which support the notion that anguidine and its derivatives block DNA synthesis via the inhibition of protein synthesis.

(i) DNA synthesis in a cell-free system ist not inhibited by derivatives of anguidine. This process can be studied with nuclei obtained from stimulated lymphocytes [7]. During incubation of this system the activated precursors of DNA, the four deoxynucleoside

\section{Table IV}

Comparison of inbibitory action of betainyl-anguidine on RNA-and protein synthesis.

Inhibition of protein synthesis ( $3 \mathrm{~h}$ incubation): similar to experiments described in Fig 1 except that after $40 \mathrm{~h}$ incubation $0.9 \mathrm{ml}$ aliquots of the cell suspension was added to $0.1 \mathrm{ml}$ Hank's solution containing inhibitor. After $1 \mathrm{~h}\left({ }^{3} \mathrm{H}\right)$ leucine was added and incorporation determined after another $2 \mathrm{~h}$ at $37^{\circ} \mathrm{C}$ (control without drug: $16229 \pm 3010$ counts $\times \min ^{-1}$ ); 20 h incubation: cssentially as described in table I (control without drug $4731 \pm 149$ counts $X$ min $^{-1}$ ). Inhibition of RNA synthesis: $3 \mathrm{~h}$ incubation with drug: drug was added to $10^{8}$ lymphocytes (table 1), $18 \mathrm{~h}$ after concanavalin A. 2 hours later $50 \mathrm{nCi}\left({ }^{14} \mathrm{C}\right.$ ) uridine (specific radioactivity $415(\mathrm{Ci} / \mathrm{mol}$ ) was added and incorporation into acid insoluble material determined after $1 \mathrm{~h}$ (control without drug $693 \pm 21$ counts $\left.\times \min ^{-1}\right) .12 \mathrm{~h}$ incubation with drug: concanavalin $\mathrm{A},\left({ }^{14} \mathrm{C}\right.$ ) uridine and drug were added together to the lymphocytes. Incorporation was determined after $12 \mathrm{~h}$ incubation (control without drug: $5094 \pm 409$ counts $\times \min ^{-1}$ ).

\begin{tabular}{|c|c|c|c|}
\hline \multirow[t]{2}{*}{ betainyl-anguidine (M) } & \multicolumn{3}{|c|}{$\begin{array}{l}\text { percent inhibition of incorporation of } \\
\text { leucine after }\end{array}$} \\
\hline & $\begin{array}{ll}3 \mathrm{~h} & 20 \mathrm{~h} \\
\text { incubation with drug }\end{array}$ & $\begin{array}{l}3 \mathrm{~h} \\
\text { incubation with }\end{array}$ & $\begin{array}{l}12 \mathrm{~h} \\
\text { drug }\end{array}$ \\
\hline $2 \times 10^{-8}$ & 62 & 28 & 41 \\
\hline $1 \times 10^{-7}$ & 100 & - & 50 \\
\hline $2 \times 10^{-6}$ & - & 52 & 69 \\
\hline
\end{tabular}




\section{Table $V$}

Dependence of inbibitory action of betainyl-anguidine on protein or DNA synthesis on the time of incubation.

Stimulated lymphocytes as described for the experiments in cell culture with betainyl-anguidine in table III were used. Short incubation with drug: 40-43 h after addition of concanavalin A; long incubation with drug: $0-40 \mathrm{~h}$ after addition of concanavalin $\mathrm{A}$; protein synthesis was measured by incubation with $\left({ }^{3} \mathrm{H}\right)$ leucine for $2 \mathrm{~h}$; DNA synthesis was determined by incubation with $\left({ }^{3} \mathrm{H}\right)$ thymidine for $2 \mathrm{~h}$.

\begin{tabular}{|c|c|c|}
\hline \multirow[t]{2}{*}{$\begin{array}{l}\text { incubation period with } \\
\text { betainyl-anguidine }\end{array}$} & \multicolumn{2}{|c|}{$\begin{array}{l}\text { molar concentration of drug required for } \\
50 \text { percent inhibition of }\end{array}$} \\
\hline & protein synthesis & DNA synthesis \\
\hline short & $1,5 \times 10^{-8}$ & $5,0 \times 10^{-8}$ \\
\hline long & $0,5 \times 10^{-8}$ & $0,5 \times 10^{-8}$ \\
\hline
\end{tabular}

triphosphates dATP, d'TP, dGTP and $\mathrm{dCTP}$, are incorporated into DNA Even in the presence of $2 \times 10^{-6} \mathrm{~mol} / \mathrm{l}$ betainylanguidine this reaction is only slightly reduced (table III).

(ii) In a cell culture protein synthesis is inhibited more rapidly and at lower concentration of the drug than DNA synthesis. Comparing the inhibitory effects of betainyl-anguidine observed after a long or a short incubation period it is immediately obvious that the inhibition of protein synthesis decreases much less than that of DNA synthesis upon shortening the incubation time. The concentration of the inhibitor has to be increased by a factor of ten to inhibit DNA synthesis to the same extent as protein synthesis during a short exposure to the drug (table V).

(iii) Specific inhibitors of protein synthesis such as puromycin or cycloheximide inhibit DNA synthesis in lymphocytes similarly to the derivatives of anguidine. This conclusion is derived from the observation that puromycin or cycloheximide inhibit DNAA synthesis in stimulated lymphocytes at the same concentration as protein synthesis. Similar to betainyl-anguidine the effect of cycloheximide on DNA synthesis increases with the length of the exposure time. Smaller concentrations of the inhibitor are sufficient at a long incubation time (table VI).

All these observations are consistent with the hypothesis that protein biosynthesis is the primary target of anguidine and its derivatives. Subsequently DNA synthesis ceases. This effect is due to the tight coupling of DNA synthesis to protein synthesis in eukaryotic cells [8] which has been demonstrated with a large number of inhibitors of protein synthesis and by use of amino acid analogues in many different types of cells [9-15]. Probably the tight coupling is mediated by the process of histone biosynthesis which is absolutely required for the formation of chromatin [16-18]. DNA biosynthesis can not be the primary target of anguidine. Otherwise any blocking of DNA synthesis by specific inhibitors should lead to a general termination of protein biosynthesis. This question was studied in the following ex- 


\section{Table VI}

Influence of inhibitors of protein synthesis on the DNA synthesis in lymphocytes.

The effect of puromycin on protein synthesis was measured under conditions similar to those described in table I except that puromycin was added $39 \mathrm{~h}$ after concanavalin A. $1 \mathrm{~h}$ later the cells were isolated by centrifugation and resuspended in medium containing, in addition to mitogen, mercaptoethanol and puromycin, $5 \mu \mathrm{Ci}\left({ }^{3} \mathrm{H}\right)$ leucine (specific radioactivity $50 \mathrm{Ci} / \mathrm{mol}$ ). Incorporation was determined after $1 \mathrm{~h}$. Control without puromycin: 4800 counts $X \min ^{-1}$. For measuring DNA synthesis the isolated cells were resuspended in medium as above except that $\left({ }^{3} \mathrm{H}\right)$ leucine was replaced by $1 \mu \mathrm{Ci}\left({ }^{3} \mathrm{H}\right)$ thymidine. Incorporation was determined after $1 \mathrm{~h}$. Control without puromycin: 6800 count $\times \mathrm{min}^{-1}$. Experiments with a $6 \mathrm{~h}$ incubation of drug: similar to those described in table III with betainyl-anguidine except that betainyl-anguidine or cycloheximide were added $38 \mathrm{~h}$ after concanavalin A. $4 \mathrm{~h}$ later $1 \mu \mathrm{Ci}\left({ }^{3} \mathrm{H}\right)$ thymidine or $5 \mu \mathrm{Ci}$ $\left({ }^{3} \mathrm{H}\right)$ leucine were added and incorporation determined after $2 \mathrm{~h}$. Controls without drug: incorporation of $\left({ }^{3} \mathrm{H}\right)$ leucine 15850 counts $\times \mathrm{min}^{-1}$; incorporation of $\left({ }^{3} \mathrm{H}\right)$ thymidine 20705 counts $\times \min ^{-1}$. Experiments with cycloheximide or betainyl-anguidine (incubation with drug for 2 or $12 \mathrm{~h}$ resp.): similar to table III except that drug was added either 29 or $39 \mathrm{~h}$ after concanavalin A. $1 \mu \mathrm{Ci}\left({ }^{3} \mathrm{H}\right)$ thymidine was added $40 \mathrm{~h}$ after mitogen and the incubation terminated after $1 \mathrm{~h}$. Control without cycloheximide ( $2 \mathrm{~h}$ pulse): 4642 counts $\times \min ^{-1}$; $(12 \mathrm{~h}$ pulse): 11242 counts $X$ $\min ^{-1}$; control without betainyl-anguidine ( $2 \mathrm{~h}$ pulse): 3972 counts $\times \min ^{-1}$; (12 h pulse): 10886 counts $\times \min ^{-1}$.

\begin{tabular}{lllll}
\hline inhibitor & $\begin{array}{l}\text { concentration } \\
(\mathrm{M})\end{array}$ & $\begin{array}{l}\text { period } \\
\text { of incubation } \\
\text { with drug }(\mathrm{h})\end{array}$ & $\begin{array}{l}\text { percent inhibition of incorporation } \\
\text { leucine }\end{array}$ & $\begin{array}{l}\text { of } \\
\text { thymidine }\end{array}$ \\
\hline $\begin{array}{l}\text { puromycin } \\
\text { cycloheximide }\end{array}$ & $1,0 \times 10^{-4}$ & 2 & 93 & 87 \\
betainyl-anguidine & $7,2 \times 10^{-7}$ & 6 & 86 & 70 \\
cycloheximide & $0,2 \times 10^{-7}$ & 6 & 92 & 83 \\
& $1,8 \times 10^{-7}$ & 2 & - & 4 \\
betainyl-anguidine & $0,2 \times 10^{-7}$ & 2 & - & 67 \\
& & 12 & - & 7 \\
\hline
\end{tabular}

periments: Cytosine arabinoside ${ }^{2}$ inhibits DNA synthesis in stimulated lymphocytes. Simultaneously biosynthesis of histones but not of other proteins decreases strongly (Fig. 2). Similarly hydroxyurea ${ }^{3}$ inhibits DNA synthesis in lymphocytes much more strongly than protein synthesis (table VII). Contrary to these inhibitors of DNA synthesis anguidine blocks protein synthesis more

2 an antimetabolite of biosynthesis of dCTP.

3 a potent inhibitor of ribonucleoside diphosphate reductase, of an enzyme required for the synthesis of DNA precursors. rapidly and more efficiently than DNA synthesis during a short incubation (table V). Therefore DNA synthesis is hardly the primary target of this drug.

If protein synthesis in vivo is the primary target of anguidine one would expect that this drug is also a very potent inhibitor of protein synthesis in a cell-free ribosomal system. Indeed, it has been demonstrated previously by many investigators that this classs of compounds inhibits initiation as well as elongation of protein synthesis on eukaryotic ribosomes in a cell-free 


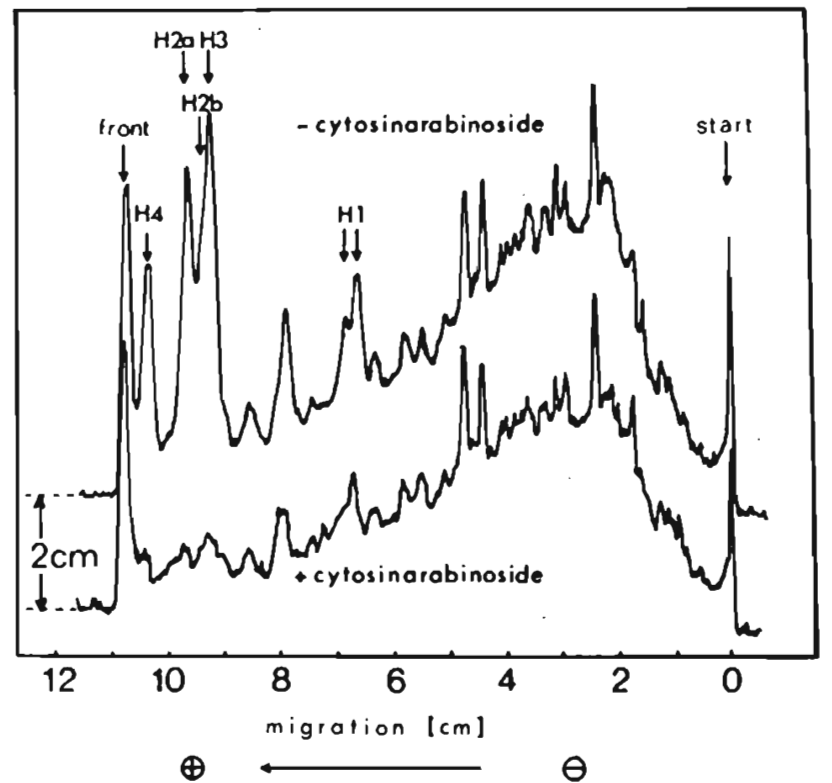

Fig. 2. Gel-electrophoretic analysis of radioactive labelled nuclear proteins synthesized during incubation of stimulated lymphocytes with $\left({ }^{14} \mathrm{C}\right)$ leucine in the presence or absence cytosine arabinoside.

Experiments were performed similar to Fig. 1 except that $20 \mu \mathrm{Ci}\left({ }^{14} \mathrm{C}\right.$ )leucine (specific radioactivity $309 \mathrm{Ci} / \mathrm{mol}$ ) and $4.5 \times 10^{-5} \mathrm{M}$ cytosine arabinoside were added. After incubation nuclei were prepared as described [7] and dissolved in dodecylsulfate as in Fig. 1. To resolve the histones the gel system described [44] was used. Nuclear proteins [7] from $2 \times 10^{6}$ lymphocytes were applied to the gel.

\section{Table VII}

Influence of inhibitors of DNA synthesis on protein synthesis in lymphocytes.

Experiments were performed similarly to those described in table III except that the drug in $0.1 \mathrm{ml}$ medium was added to $0.9 \mathrm{ml}$ aliquots of stimulated lymphocytes 39 hours after mitogen. One hour later $\left({ }^{3} \mathrm{H}\right)$ thymidine or $\left({ }^{3} \mathrm{H}\right)$ leucine were added and incorporation into acid insoluble material measured after another 2 hours of incubation; controls without drug for DNA synthesis: 1) $14381 \pm 1046$ counts $\times \min ^{-1}$ (experiments with hydroxyurea); 2) $12240 \pm 755$ counts $X$ $\min ^{-1}$ (experiments with cytosine arabinoside). Controls without drug for protein synthesis: 1) $8917 \pm 223$ (experiments with hydroxyurea); 2) 6240 counts $\times \min ^{-1}$ (experiments with cytosine arabinoside).

inhibitor concentration

(M) percent inhibition of incorporation of thymidine

$$
\text { leucine }
$$

\begin{tabular}{lrlr}
\hline hydroxyurea & $1,3 \times 10^{-4}$ & 77 & 10 \\
& $13,0 \times 10^{-4}$ & 96 & 36 \\
cytosine & $4,1 \times 10^{-7}$ & 65 & 0 \\
arabinoside & $41,0 \times 10^{-7}$ & 91 & 10
\end{tabular}




\section{Table VIII}

Influence of inhibitors of protein synthesis in cell culture on the ribosomal synthesis of proteins in a cell-free system.

Experiments in cell culture: Essentially as described in table IV except that verrucarin $A$ or betainyl-anguidine were added $39.5 \mathrm{~h}$ after concanavalin $\mathrm{A}$ and $\left({ }^{3} \mathrm{H}\right)$ leucine $30 \mathrm{~min}$ later. Incubation was terminated $1 \mathrm{~h}$ later. Experiments with cycloheximide were carried out similarly to the experiments in cell culture with betainyl-anguidine described in table III except that the drug was added $38 \mathrm{~h}$ after concanavalin A. 2 h later $\left({ }^{3} \mathrm{H}\right)$ leucine was added and the incubation continued for 2 more hours. In vitro experiments: essentially as described [40] with rat liver supernatant [41]. Ribosomes were prepared from lymphocytes stimulated for $42 \mathrm{~h}$ with concanavalin A (table III). Experiments with added mRNA: $50 \mu \mathrm{g}$ poly $\mathrm{rU}$ and $1 \mu \mathrm{Ci}\left({ }^{3} \mathrm{H}\right)$ phenylalanin (specific radioactivity $9 \mathrm{Ci} / \mathrm{mmol}$ ); time of incubation $40 \mathrm{~min}$ except for cycloheximide $(20 \mathrm{~min})$; control without drug: about 4100 counts $\times \mathrm{min}^{-1}$ in both experiments. In the experiments using endogenous mRNA $1 \mu \mathrm{Ci}\left({ }^{3} \mathrm{H}\right)$ leucine was used as radioactive precursor; time of incubation: $20 \mathrm{~min}$. Control without drug: 5195 counts $\times \min ^{-1}$.

\begin{tabular}{|c|c|c|c|}
\hline inhibitor & \multicolumn{3}{|c|}{$\begin{array}{l}\text { molar concentration required for } \\
\text { in cell culture } 50 \text { percent inhibition of protein synthesis } \\
\text { in a cell-free system }\end{array}$} \\
\hline & & & no effect at \\
\hline verrucarin A & $2 \times 10^{-8}$ & $2 \times 10^{-5}$ & $2 \times 10^{-5}$ \\
\hline betainyl-anguidine & $2 \times 10^{-8}$ & $2 \times 10^{-5}$ & $>2 \times 10^{-4}$ \\
\hline cycloheximide & $4 \times 10^{-7}$ & $4 \times 10^{-4}$ & $1 \times 10^{-3}$ \\
\hline
\end{tabular}

system $[5,6,19-25]$. It is rather striking, however, that usually more than $10^{-6} \mathrm{~mol} / \mathrm{l}$ anguidine or verrucarin $\mathrm{A}$ are required for inhibition under these conditions. We have confirmed these observation for the inhibition of protein synthesis in a cell-free system with ribosomes from stimulated lymphocytes using either polyribouridylic acid or endogeneous RNA as messenger. To obtain $50 \%$ inhibition $2 \times 10^{-5} \mathrm{~mol} / 1$ of the toxin is required (table VIII). Obviously in this system protein synthesis is also much less sensitive to betainyl-anguidine than in cell culture. This unexpected discrepancy between the effect in cell culture and in a cell-free system has been observed with other inhibitors of protein synthesis such as cycloheximide [20,26-28] and emetine
$[12,28]$ in various eukaryotic cells and cellfree systems. We have confirmed the observation with cycloheximide in stimulated lymphocytes (table VIII). It may be explained by assuming the presence or absence of a soluble protein factor which determines the sensitivity to the inhibitors. On the basis of this assumption the concentration of such a soluble factor would control the inhibitory activity of the drugs. Indeed, such a soluble protein has been isolated from the supernatant of a yeast lysate which renders sensitivity towards cycloheximide to the cell-free system from yeast [29].

\section{Ovalicin}

Ovalicin has been isolated from the culture medium of the ascomycete $P$ seud- 
<smiles>COC1C(=O)CCC2(CO2)C1(O)C1(C)OC1CC=C(C)C</smiles>

Ovalicin

eurotium ovalis Stolk by SIGG and Weber. The same authors have determined its chemical structure [30]. Its immunosuppressive activity in vivo deserves particular attention: the number of antibody producing cells in the spleen of mice immunized with sheep red blood cells decreases to less than one per cent if $600 \mathrm{mg}$ ovalicin per $\mathrm{kg}$ mouse is injected one day after immunisation. With later injection the inhibitory effect declines rapidly. Similarly the graft versus host reaction is distinctly delayed by ovalicin. The drug reduces the number of mitoses in spleen cells of immunised mice whereas the mitotic index in the jejunum is unchanged [31, 32]. These observations suggested a study of the action of ovalicin on cells of the lymphatic system. Following our proposal SCHimpl and WeCKer have investigated the effect of the drug on the induction of antibody production in cultures of mouse spleen cells [33]. Surprisingly the activity of ovalicin in this system turned out to be much higher than in the animal. Even at a concentration of $4 \times 10^{-9} \mathrm{~mol} / \mathrm{l}$ a distinct inhibition was observed [34]. One reason for the apparently lower activity in the animal may be the much higher metabolic turnover rate of the drug.

We decided to analyse the mode of action of ovalicin by measuring a more convenient reaction in a lympocyte cell culture system. For this purpose we have chosen thymidine incorporation into DNA as an indicator of cell proliferation in lymphocytes stimulated by mitogen. If ovalicin is added together with concanavalin A to murine splenic lymphocytes incorporation of radioactively labelled thymidine into DNA during the S-phase is strongly reduced. Even at a concentration of $2 \times 10^{-10}$ $\mathrm{mol} / \mathrm{l}$ ovalicin a $50 \%$ decrease of thymidine incorporation is observed (table III). However, at much higher concentrations of the drug inhibition of DNA synthesis is by no means complete. The extent of this ovalicin resistant thymidine incorporation depends on many factors such as the concentration of the mitogen, cell density, presence of mercaptoethanol or time of measurement of DNA synthesis.

Ovalicin is not only active on DNA synthesis induced artificially by plant lectins such as concanavalin A, purified phytohaemagglutinin or poke weed mitogen (data not shown). In a mixed lymphocyte culture proliferation is induced by the presence of several different antigenic determinants on the cell surface of the allogeneic lymphocytes. In this system ovalicin also is strongly inhibitory to DNA synthesis (table IX).

All these observations demonstrate that ovalicin is one of the most potent low-molecular inhibitors of proliferation of lymphocytes.

A suspension of spleen cells contains populations of many different cells, among them lymphocytes of $\mathrm{B}$ and $\mathrm{T}$ type. Therefore the question arises if ovalicin inhibits proliferation only in certain types of cells. B and T cells may 


\section{Table IX}

Influence of ovalicin on the thymidine incorporation into proliferating lymphocytes.

Mixed lymphocyte culture: A mixture of $5 \times 10^{5}$ spleen lymphocytes each from C $57 \mathrm{Bl} / 6$ and DBA/2 mice were incubated at $37^{\circ} \mathrm{C}$ with or without drug in Eagle's MEM containing $5 \%$ fetal calf serum [38] (total volume $1 \mathrm{ml}$ ). After $48 \mathrm{~h} \mu \mathrm{Ci}\left({ }^{3} \mathrm{H}\right)$ thymidine (specific radioactivity $10 \mathrm{Ci} / \mathrm{mmol}$ ) were added and the incubation continued for $6 \mathrm{~h}$.

Lymphoblastoma cells: Exponentially growing cells were cultured at $37^{\circ} \mathrm{C}$ in Dulbecco's modified Eagle's medium (without nonessential amino acids) containing $10 \%$ fetal calf serum (total volume $15 \mathrm{ml}$ ) with or without drug. After $48 \mathrm{~h} 0.9 \mathrm{ml}$ aliquots were transferred to test tubes, $1 \mu \mathrm{Ci}$ $\left({ }^{3} \mathrm{H}\right)$ thymidine (specific radioactivity $0.5 \mathrm{Ci} / \mathrm{mmol}$ ) in $0.1 \mathrm{ml}$ was added and the incubation continued for $1 \mathrm{~h}$.

Spleen cells (athymic nu/nu mouse): $10^{6}$ cells were incubated in the presence of $2 \mu \mathrm{g}$ lipopolysaccharide and ovalicin for $36 \mathrm{~h}$ (total volume $1 \mathrm{ml}$ ). Subsequently $1 \mu \mathrm{Ci}\left({ }^{3} \mathrm{H}\right.$ )thymidine was added and the incubation continued for $24 \mathrm{~h}$.

Human peripheral blood lymphocytes: lymphocytes from fresh human blood (42) were treated as described under spleen cells except that $5 \mu \mathrm{g} / \mathrm{ml}$ Concanavalin A was used as mitogen.

\begin{tabular}{|c|c|c|c|c|}
\hline \multirow[t]{2}{*}{ type of cell } & \multirow[t]{2}{*}{ ovalicin $(\mathrm{mol} / \mathrm{l})$} & \multicolumn{2}{|c|}{$\begin{array}{c}\text { incorporation of }\left[{ }^{3} \mathrm{H}\right] \text { thymidine } \\
\left(\text { counts } \times \min ^{-1}\right)\end{array}$} & \multirow{2}{*}{$\begin{array}{l}\text { inhibition } \\
(\%)\end{array}$} \\
\hline & & + ovalicin & - ovalicin & \\
\hline $\begin{array}{l}\text { mixed mouse lymphocytes } \\
\qquad(\text { C } 57 \mathrm{Bl} / 6+\mathrm{DBA} 2)\end{array}$ & $0,3 \times 10^{-11}$ & $2538 \pm 917$ & $6471 \pm 1305$ & 61 \\
\hline $\begin{array}{l}\text { S } 49.1 \text { lymphoblastoma } \\
\text { spleen cells }\end{array}$ & $1,0 \times 10^{-8}$ & $35410 \pm 760$ & $70820 \pm 340$ & 50 \\
\hline (athymic nu/nu mouse) & $3,0 \times 10^{-7}$ & $4609 \pm 343$ & $13557 \pm 1213$ & 65 \\
\hline peripheral human lymphocytes & $2,0 \times 10^{-7}$ & $1971 \pm 260$ & $3131 \pm 226$ & 37 \\
\hline
\end{tabular}

be stimulated separately by various mitogens such as concanavalin A which induces only $\mathrm{T}$ cells whereas lipopolysaccharide from the outer membrane of gram-negative bacteria induces only $B$ cells [35]. In each case the proliferation induced by these type-specific mitogens is inhibited by very small concentrations of ovalicin (table IX). This is also true for the mitogen induced proliferation of human peripheral lymphocytes (table IX). Similarly, thymidine incorporation in transformed lymphocytes such as monoclonal S 49.1 mouse lymphoma cells [36] is strongly reduced after $48 \mathrm{~h}$ incubation with the toxin (table IX). This observation demonstrates the direct action of ovalicin on lymphocytes. Its action is not mediated by cell-cell interaction, for example via macrophages.

The inhibitory action of ovalicin on cells different from those of the lymphatic system has also been studied. Thymidine incorporation in 3T6 mouse fibroblasts or HeLa cells is distinctly less inhibited by ovalicin. Incubation with $2 \times 10^{-7} \mathrm{~mol} / \mathrm{l}$ drug for two days results in only $30-40 \%$ inhibition whereas at this concentration inhibition in S 49.1 lymphoma cells is $80 \%$ at this concentration. However, the smaller inhibitory effect on 3T6 or HeLa cells is already detectable at the low drug concentration of $2 \times 10^{-9} \mathrm{~mol} / \mathrm{l}$ (data not shown). These observations suggest 
that lymphocytes are more susceptible to the action of ovalicin than other cells, in agreement with observations on the effects of the drug on the various animal tissues [31].

In the experiments reported so far incorporation of the nucleoside thymidine into DNA was used as analytical tool to demonstrate the activity of ovalicin. If DNA synthesis is directly affected the drug should be able to block the incorporation of deoxyribonucleoside triphosphates into DNA in a cell free system from lymphocytes [7]. However, even at concentration of $3 \times 10^{-6}$ $\mathrm{mol} / \mathrm{l}$ ovalicin does not act inhibitory in this system (table III). Obviously the polycondensation of precursors to DNA is not the target of the drug. On the other hand DNA synthesis is clearly reduced in a cell-free system prepared from lymphocytes which had been preincubated with ovalicin compared with the activity of a system from untreated cells (table X). This observation supports the notion that ovalicin inhibits the formation of an essential element of the DNA synthesizing machinery.

If this notion is correct it is be expected that the time of addition of the inhibitor to the cell culture should clearly influence the extent of inhibition. Indeed, this notion has been confirmed. If ovalicin is added to a spleen cell culture at various times after mitogenic stimulation maximal inhibition is observed only when the drug is added until the 6 th to the 8 th hour after mitogen. If added $16-20 \mathrm{~h}$ after mitogen no effect is measured on the DNA synthesis measured 14 h later (Fig. 3). Obviously the early phase of lymphocyte stimulation is particularly sensitive to the inhibitor.

On the other hand, characteristic reactions occurring immediately after addition of the mitogen are not at all reduced by the drug. This conclusion may be derived from the observation that ovalicin added $6 \mathrm{~h}$ after the mitogen shows its full inhibitory activity (Fig. 3). The same conclusion is derived from the investigation of the lipid

\section{Table $X$}

Influence of ovalicin on the incorporation of $\left({ }^{3} H\right) d T T P$ into DNA of nuclei of lymphocytes. The experiment was performed as described in table III except that nuclei were prepared from lymphocytes $\left(2 \times 10^{8}\right.$ cells $\left./ \mathrm{ml}\right)$ stimulated for $46 \mathrm{~h}$ with $1 \mu \mathrm{g} / \mathrm{ml}$ concanavalin $\mathrm{A}$ in the absence of mercaptoethanol; concentration of ovalicin: $7 \times 10^{-7} \mathrm{~mol} / \mathrm{l}$.

\begin{tabular}{ll}
\hline $\begin{array}{l}\text { pretreatment of } \\
\text { lymphocytes }\end{array}$ & $\begin{array}{l}{\left[{ }^{3} \mathrm{H}\right] \mathrm{dTTP} \text { incorporation into nuclei }} \\
\left(\text { counts } \times \min ^{-1} \times 10^{-6} \text { nuclei }\right)\end{array}$ \\
\hline+ Con A & 115 \\
+ ovalicin & \\
+ Con A & 231 \\
- ovalicin & \\
- Con A & 31 \\
\hline
\end{tabular}




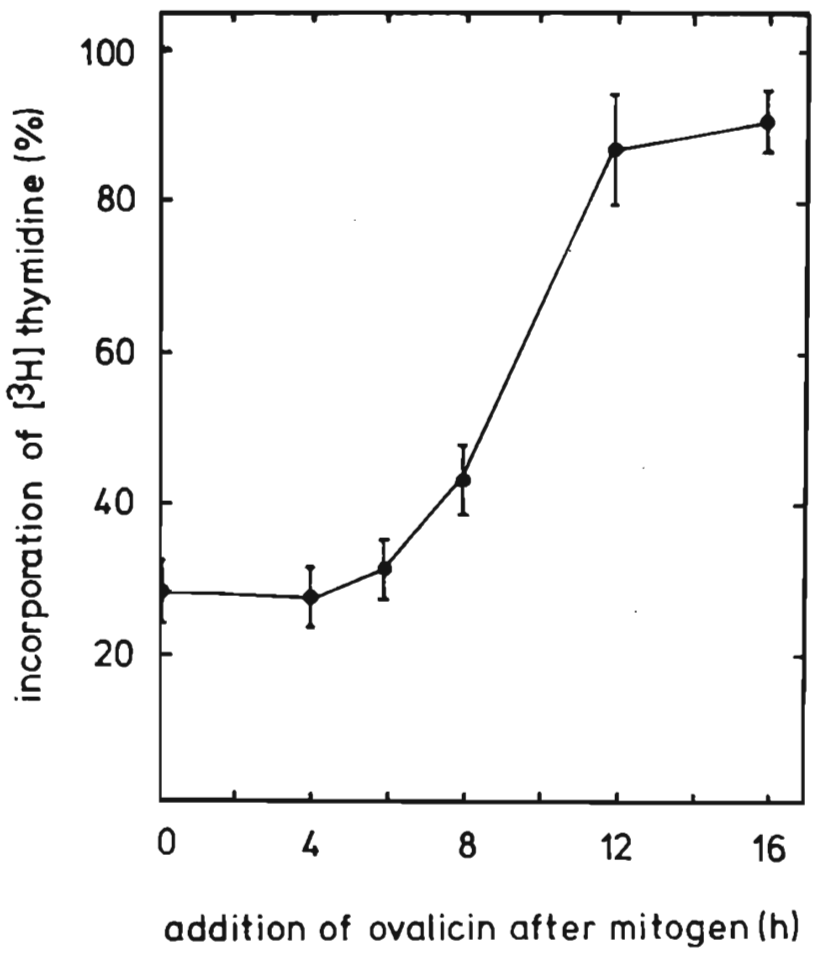

Fig. 3. Influence of the time of addition of ovalicin on $\left({ }^{3} \mathrm{H}\right)$ thymidine incorporation into DNA of stimulated lymphocytes.

$1 \mu \mathrm{g} / \mathrm{ml}$ concanavalin A was added to $10^{6}$ lymphocytes (preincubated for $12 \mathrm{~h}$ at $37^{\circ} \mathrm{C}$ ). $2 \times 10^{-7} \mathrm{M}$ ovalicin were added after the time indicated on the abscissa. $30 \mathrm{~h}$ after mitogen $\left({ }^{3} \mathrm{H}\right)$ thymidine was added and the incubation continued for 6 h. Controls without ovalicin: $21835 \pm 1094$ counts $X$ $\min ^{-1}=100 \%$.

turnover which, in lymphocyte membranes, is significantly increased very soon after addition of mitogen [37]. The lipid turnover is increased also in presence of ovalicin (table XI).

These observations may lead to the conclusion that ovalicin acts on stimulated lymphocytes only during a very short phase of the cell cycle (6-12 h after addition of mitogen). However, this conclusion could not be confirmed. Rather a $14-16 \mathrm{~h}$ incubation period of the drug is required for maximum inhibition of stimulated spleen lymphocytes from mouse as is shown by the following experiments: in the first experiment the drug was added to the cell culture various times after the mitogen. $20 \mathrm{~h}$ after addition of the mitogen the inhibitor was removed from all samples by repeated washing (Fig. $4(0)$ ). The strongest inhibition of DNA synthesis was observed when ovalicin had acted on the cells for at least $16 \mathrm{~h}$. In the second experiment the drug was added uniformly to all samples $6 \mathrm{~h}$ after mitogen. It was then removed from the samples after 2-14 h incubation (Fig. $4(\Delta))$. As in the previous experiment an incubation period of at 


\section{Table XI}

Influence of ovalicin on the incorporation of $\left({ }^{14} \mathrm{C}\right)$ acetate into lecithin from lymphocytes.

Lymphocytes from spleen $\left(2 \times 10^{8}\right.$ cells/ml, preincubated for $\left.15 \mathrm{~h}\right)$ were incubated in Eagle's MEM containing $2.5 \%$ calf serum, $1 \mu \mathrm{g} / \mathrm{ml}$ concanavalin A and $10 \mu \mathrm{mol} / 1$ mercaptoethanol. Incorporation of $\left({ }^{14} \mathrm{C}\right)$ acetate $(56 \mathrm{Ci} / \mathrm{mol})$ into lecithin was measured essentially as described [37]. Concentration of ovalicin: $2 \times 10^{-7} \mathrm{~mol} / 1$ (added with Con A).

\begin{tabular}{lll}
\hline additions & $\begin{array}{l}\text { incorporation of }\left[{ }^{14} \mathrm{C}\right] \text { acetate into } \\
\text { lecithin from lymphocytes } \\
\text { between } 0-4 \text { h after addition } \\
\left.\text { of Con A (counts } \times \mathrm{min}^{-1}\right)\end{array}$ & $\begin{array}{l}\text { lecithin content } \\
\text { (in \% of total lipids) }\end{array}$ \\
\hline+ Con A & 904 & 15.6 \\
+ ovalicin & & 14.3 \\
+ Con A & 803 & 13.5 \\
\hline
\end{tabular}

least $14 \mathrm{~h}$ is required to obtain the strongest inhibitory effect. This long incubation period may be required for several reasons: existence of various populations of cells in the culture, a very slow permeation of the drug into the cells or a metabolic activation of ovalicin.

However we were unable to detect any metabolic products in the medium of the cell culture after a long incubation with the drug which would inhibit stimulated lymphocytes with higher activity (data not shown).

The preceding experiments show that the cell cultures have to be incubated with ovalicin for a rather long period of time to obtain a maximal inhibitory effect. But at which time can the first effect of the drug be observed? If the rate of DNA synthesis is measured using short pulses of radioactively labelled thymidine and starting immediately after addition of mitogen, an incorporation of thymidine into DNA is observed as soon as 7-8 $\mathrm{h}$ after mitogen (Fig. 5). Although exceedingly small, it is clearly higher than that observed in a cell culture not having received mitogen. If $2 \times 10^{-7} \mathrm{~mol} / 1$ ovalicin are added together with the mitogen even this very early incorporation is distinctly inhibited (Fig. 5). Again the effect of ovalicin is not observed immediately after addition but requires an incubation period of several hours (data not shown).

All these observations are at variance with DNA synthesis as a direct target of the drug. Therefore the action of the toxin on the biosynthesis of other macromolecules has also been investigated.

Incorporation of radioactively labelled uridine into the acid insoluble material of cell lysate was used to assay for the biosynthesis of RNA. Incorporation of uridine into RNA is significant even in resting lymphocytes. It is 


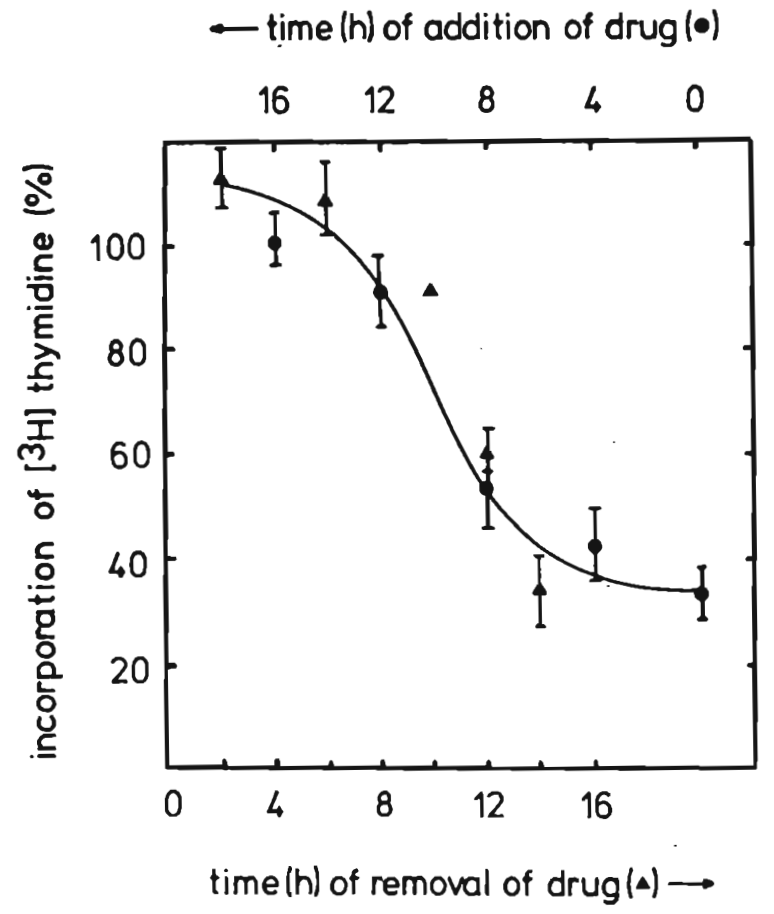

Fig. 4. Influence of the length of incubation period of lymphocytes with ovalicin on the inbibition of DNA synthesis.

$1 \mu \mathrm{g}$ Con $\mathrm{A}$ was added to $10^{\circ}$ lymphocytes (preincubated for $12 \mathrm{~h}$ at $37^{\circ} \mathrm{C}$ ) in $1 \mathrm{ml}$ medium. In one series of experiments $\left(-3 \times 10^{-8} \mathrm{M}\right.$ ovalicin were added after addition of Con $\mathrm{A}$ at the time indicated on the upper abscissa and the drug removed $20 \mathrm{~h}$ after addition of mitogen by sedimenting of the cells and resuspending in fresh medium. This washing procedure was repeated twice. Controls were treated similarly. $25 \mathrm{~h}$ after addition of mitogen $1 \mu \mathrm{Ci}\left({ }^{3} \mathrm{H}\right)$ thymidine was added and the incubation continued for $11 \mathrm{~h}$. In a second series of experiments $(\boldsymbol{\Delta}) 3 \times 10^{-9} \mathrm{M}$ ovalicin were added $6 \mathrm{~h}$ after mitogen and removed by repeated washings after the times indicated on the lower abscissa. Controls without drug: $29198 \pm 2689$ counts $\times \min ^{-1}=100 \%$.

not reduced even by $3 \times 10^{-7} \mathrm{~mol} / \mathrm{l}$ ovalicin. In lymphocytes stimulated with concanavalin A RNA synthesis is only weakly inhibited after $20 \mathrm{~h}$ incubation with the drug (Table XII). Obviously, RNA synthesis as followed by total incorporation of a precursor, is not the target of the drug.

Furthermore, this observation also indicates that the production of energy in lymphocytes is not the target of ovalicin because RNA synthesis is strongly dependent on this process.
In eukaryotic cells, DNA synthesis is tightly coupled to protein synthesis as has been discussed in the section on anguidine. Therefore the influence of ovalicin on protein synthesis has been investigated. The incorporation of radioactively labelled leucine into the acid insoluble material of cell lysates was used to assay for protein biosynthesis. $14 \mathrm{~h}$ incubation with $2 \times 10^{-7}$ $\mathrm{mol} / \mathrm{l}$ ovalicin leads to a $20 \%$ reduction of protein synthesis whereas the small extent of DNA synthesis is already redu- 


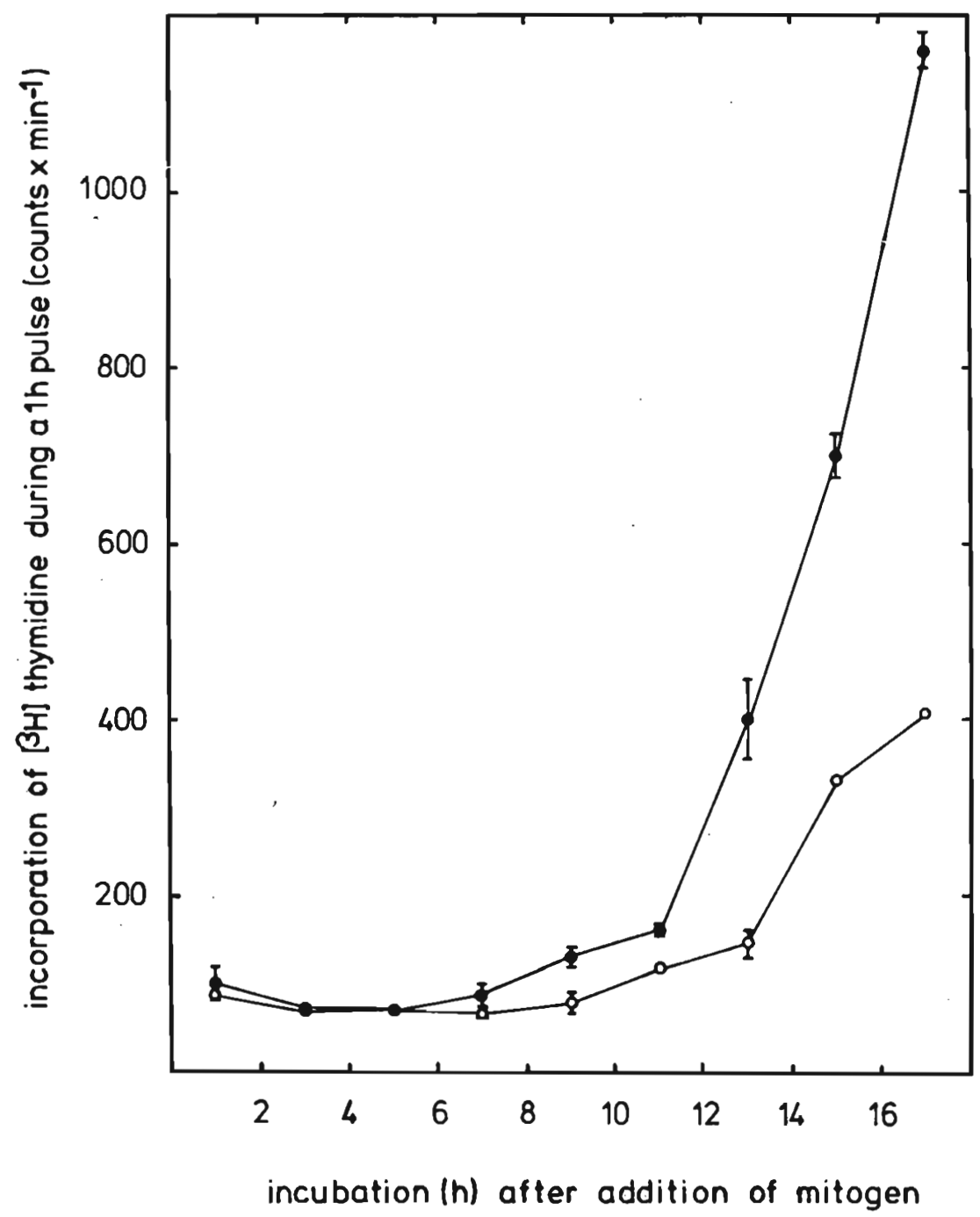

Fig. 5. Influence of ovalicin on DN A synthesis in lymphocytes observed shortly after addition of mitogen.

Lymphocytes were stimulated as described in table XI. Incorporation of $\left({ }^{3} \mathrm{H}\right)$ thymidine $(0.5 \mathrm{Ci} /$ $\mathrm{mmol}, 1 \mu \mathrm{Ci} / \mathrm{ml}$ ) during a one hour pulse was measured; concentration of ovalicin used: $2 \times$ $10^{-7} \mathrm{~mol} / \mathrm{l}$.

ced by $60-70 \%$ at this early phase of the cell cycle (table XIII). The inhibition of protein synthesis is increased to $40 \%$ when the incubation period with the drug is extended to $40 \mathrm{~h}$ (table XIII). This increased extent of inhibition may be the consequence of the blocked biosynthesis of DNA as has been discussed above. In this context we wish to mention the observation that the elongation process of protein biosynthesis as measured with ribosomes from stimulated 


\section{Table XII}

Infuence of ovalicin on the incorporation of $\left({ }^{14} \mathrm{C}\right)$ uridine into $R N A$ of stimulated lymphocytes. $1 \mu \mathrm{g}$ concanavalin $\mathrm{A} / \mathrm{ml}$ and $3 \times 10^{-7} \mathrm{~mol} / \mathrm{l}$ ovalicin were added to $10^{6}$ lymphocytes $/ \mathrm{ml}$ (preincubated for $12 \mathrm{~h}$ at $37^{\circ} \mathrm{C}$ ). After $20 \mathrm{~h} 80 \mathrm{nCi}\left({ }^{14} \mathrm{C}\right.$ ) uridine (specific radioactivity $414 \mathrm{Ci} / \mathrm{mol}$ ) were added and the incubation continued for $1 \mathrm{~h}$.

\begin{tabular}{ll}
\hline additions & $\begin{array}{l}\text { incorporation of }\left[{ }^{14} \mathrm{C}\right] \text { uridine during } \\
\left.\text { a one hour pulse (counts } \times \mathrm{min}^{-1}\right)\end{array}$ \\
\hline+ Con A & 2651 \\
+ ovalicin & \\
+ Con A & 3419 \\
- ovalicin & \\
- Con A & 1170 \\
+ ovalicin & \\
- Con A & 1186 \\
- ovalicin &
\end{tabular}

\section{Table XIII}

Inbibition by ovalicin of the incorporation of $\left({ }^{3} \mathrm{H}\right)$ leucine or $\left({ }^{3} \mathrm{H}\right)$ thymidine into acid insoluble material of stimulated lymphocytes.

Preincubated lymphocytes were stimulated essentially as described in table XI. Protein synthesis was followed by incorporation of $\left({ }^{3} \mathrm{H}\right.$ ) leucine (specific radioactivity $57 \mathrm{Ci} / \mathrm{mol}$ when added $12 \mathrm{~h}$ after mitogen, $13 \mathrm{Ci} / \mathrm{mol}$ when added $36 \mathrm{~h}$ after mitogen) during a $2 \mathrm{~h}$ pulse essentially as described in table $\mathrm{I}$. Incorporation of $\left({ }^{3} \mathrm{H}\right)$ thymidine (specific radioactivity $0.5 \mathrm{Ci} / \mathrm{mol}$ ) during a $2 \mathrm{~h}$ pulse was determined essentially as described in table III. Concentration of ovalicin: $2 \times 10^{-7} \mathrm{~mol} / 1$ (added with Con A).

\begin{tabular}{lllr}
\hline additions & $\begin{array}{l}\text { time of addition of } \\
\text { radioactive precursor }\end{array}$ & $\begin{array}{l}\text { incorporation of } \\
{\left[\begin{array}{l}\left.{ }^{3} \mathrm{H}\right] \text { leucine } \\
\left(\text { counts } \times \mathrm{min}^{-1}\right)\end{array}\right.}\end{array}$ & $\begin{array}{l}\text { incorporation of } \\
{\left[\begin{array}{l}\left.{ }^{3} \mathrm{H}\right] \text { thymidine } \\
\left(\text { counts } \times \mathrm{min}^{-1}\right)\end{array}\right.}\end{array}$ \\
\hline+ ovalicin & 12 & $5700 \pm 139$ & $443 \pm 30$ \\
- ovalicin & 12 & $7741 \pm 27$ & $1094 \pm 28$ \\
+ ovalicin & 36 & $4391 \pm 62$ & $13250 \pm 934$ \\
\hline ovalicin & 36 & $8565 \pm 308$ & $40594 \pm 1664$ \\
\hline
\end{tabular}

lymphocytes in a cell-free system is not inhibited by $3 \times 10^{-7} \mathrm{~mol} / 1$ ovalicin (table XIV).

If the inhibition of protein biosynthesis by the toxin is the direct consequence of the inhibition of DNA synthesis the formation of the histones should be affected particularly as has been shown above for cytosine arabino- side by electrophoretic analysis (Fig. 2). However, this is not found. In the presence of ovalicin the formation of all proteins is uniformly reduced (data not shown).

Summarizing the numerous observations reported we have to conclude that neither DNA nor protein synthesis is a direct target of ovalicin. This notion is 
Table XIV

Effect of ovalicin on the poly $r U$ directed synthesis of polyphenylalanine in a cell-free system with ribosomes from stimulated lymphocytes.

Ribosomes were prepared from lymphocytes stimulated as described in table XI except that mercaptoethanol was added $23 \mathrm{~h}$ after addition of mitogen. The experiments with the cell-free system were performed as in table VIII except that the time of incubation was $15 \mathrm{~min}$.

\begin{tabular}{ll}
\hline additions & $\begin{array}{l}\text { incorporation of }\left[{ }^{3} \mathrm{H}\right] \text { phenylalanine } \\
\left(\text { counts } \times \mathrm{min}^{-1}\right)\end{array}$ \\
\hline $\begin{array}{l}\text { no } \\
+0.7 \times 10^{-6} \mathrm{~mol} / 1\end{array}$ & $2630 \pm 494$ \\
$\begin{array}{l}\text { ovalicin } \\
+1 \times 10^{-5} \mathrm{~mol} / 1\end{array}$ & $2707 \pm 310$ \\
$\begin{array}{l}\text { ovalicin } \\
\text { without } \\
\text { ribosomes }\end{array}$ & $2545 \pm 293$ \\
& $1040 \pm 271$ \\
\hline
\end{tabular}

supported by a comparison of the action of ovalicin with that of cycloheximide or cytosine arabinoside on the transformation of small resting lymphocytes into large blast cells. After addition of the mitogen to a cell culture the average diameter of the cells increases up to the 48th hour of incubation as measured in the microscope. If cycloheximide is added together with the mitogen the average diameter of the lymphocytes remains unchanged as in the absence of mitogen. Obviously continuous protein synthesis is required for blast cell formation. In the presence of cytosine arabinoside the average cell diameter increases up to the 24 th hour almost as much as in the absence of this specific inhibitor of DNA synthesis. During the following day no further increase is observed. The effect of ovalicin is very different from that of the drugs mentioned above. Here the formation of blast cells continues up to two days of incubation although it is distinctly slower than in the absence of ovalicin (Fig. 6). In contrast DNA synthesis, as measured simultaneously by incorporation of thymidine into the acid insoluble material of the cells, is inhibited very extensively (Fig. 6). These oberservations indicate that the mechanism of action of ovalicin is very different from that of specific inhibitors of protein and DNA synthesis. Further investigations to pinpoint the target will be required. They promise to be rewarding since they will reveal the reason for the exceptionally high sensitivity of lymphocytes to the toxin as well as a key reaction crucial for lymphocyte proliferation, since otherwise $10^{-10} \mathrm{~mol} / \mathrm{l}$ ovalicin would not be expected to act inhibitory.

\section{Acknowledgements}

These investigations have been supported in part by the Sonderforschungsbereich 105 (Cytologische Grundlagen der experimentellen Biologie) and by the Fonds der Chemischen Industrie. The toxins used have been kindly provided by Drs. H.-P. Sigg and H. Staehelin, Sandoz AG, 


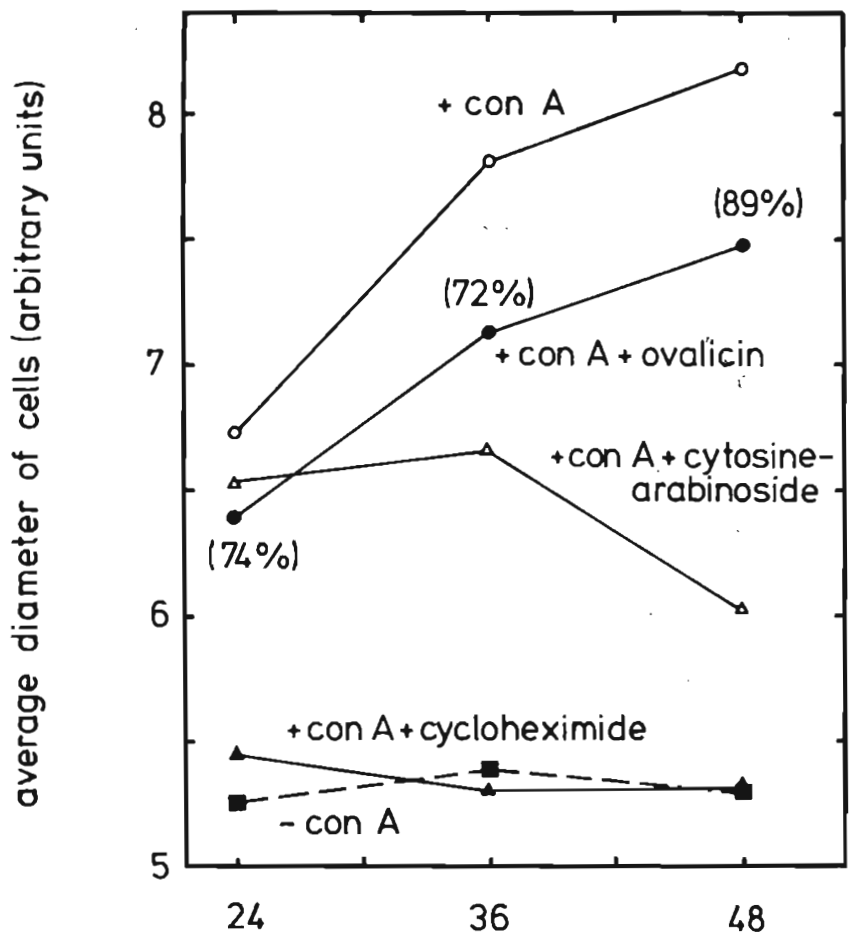

\section{incubation (hours)}

Fig. 6. Inhibition of the transformation of small lymphocytes into blast cells by ovalicin, cytosine arabinoside or cyclobeximide.

Lymphocytes were stimulated as described in table XI. Drugs were added togehter with the mitogen: $2 \times 10^{-7} \mathrm{M}$ ovalicin, $1 \times 10^{-6} \mathrm{M}$ cycloheximide or $1 \times 10^{-5} \mathrm{M}$ cytosine arabinoside, respectively. About $5 \times 10^{5}$ washed cells (in $0.25 \mathrm{ml}$ ) were mixed with $0.5 \mathrm{ml}$ warm $0.5 \%$ agarose in phosphate-buffered saline, and applied to slides. The coated slides were treated with $0.5 \%$ glutaraldehyde in phosphate-buffered saline, washed three times for $5 \mathrm{~min}$ in destilled water, air-dried and Giemsastained [45]. The diameter of the stained cells was estimated at a magnification of 1:1250 in arbitrary units and the average diameter of 250 cells calculated. DNA synthesis (values in per cent are given in brackets) at 24,36 and $48 \mathrm{~h}$ of incubation after addition of concanavalin $A$ was determined by an one hour $\left({ }^{3} \mathrm{H}\right)$ thymidine pulse $(1 \mu \mathrm{Ci} / \mathrm{ml} ; 0.5 \mathrm{Ci} / \mathrm{mmol})$ in $0.9 \mathrm{ml}$ aliquots of the cell culture. $100 \%$ of DNA synthesis at 24,36 and $48 \mathrm{~h}$ respectively: $19957 \pm 84,50285 \pm$ $3286,116805 \pm 222$ counts $\times \mathrm{min}^{-1}$, respectively. In the presence of cycloheximide or cytosine arabinoside the incorporation of thymidine into the acid-insoluble material of the cells is neglegible.

and by Dr. C. Tамm, Institut für Organische Chemie, University of Basel. The first investigations on the mode of action of betainyl-anguidine were performed by Dr. T. NEUDECKER in our laboratory. We wish to express our deep gratitude to Drs. A. SCHIMPL, E. WeCKER and C. JUNGwiRTH, Institut für Virologie und Immunbiologie, University of Würzburg, for advice, suggestions and many helpful discussions and for providing us with informations about unpublished experiments. We are obliged to Dr. U. Gehring, Institut für Biologische Chemie, University of Heidelberg, for providing us with ly'mphoblastoma cells and for advice to grow them in cell culture and to Dr. E.-L. WINNAKXER and his group, Institut für Biochemie, University of München, for help in the experiments with HeLa and 3T6 cells. 


\section{References}

1. Tamm, Ch.: Fortschr. Chem. org. Naturst. 31, 63 (1974).

2. Staehelin, H., M. E. Kalberer-Rüsch, E. Signer and S. Lazáry: Arzneim. Forsch. 18, 989 (1968).

3. Hartmann, G., K. O. Honikel, F. Knüsel and J. Nüesch: Biochim. Biophys. Acta 145, 843 (1967).

4. Moss, B. and E. N. Rosenblum: J. Mol. Biol. 81, 267 (1973).

5. Ueno, Y. and N. Shimada: Chem. Pharm. Bull. 22, 2744 (1974).

6. Liao, L.-L., A. P. Grollman and B. B. Horwitz: Biochem. Biophys. Acta 454, 273 (1976).

7. Benz, W. C. and J. L. Strominger: Proc. Natl. Acad. Sci. USA 72, 2413 (1975).

8. Powell, W. R.: Biochim. Biophys. Acta 55, 979 (1962).

9. Mueller, G. C., K. Kajiwara, E. Stubblefield and R. R. Rueckert: Cancer Res. 22, 1084 (1962).

10. Kerridge, D.: J. Gen. Microbiol. 19, 497 (1958).

11. Bennett, L. L. jr., D. Smithers and C. T. Ward: Biochim. Biophys. Acta 87, 60 (1964).

12. Grollman, A. P.: J. Biol. Chem. 243, 4089 (1968).

13. Tyrsted, G., B. Munch-Petersen and L. Cloos: Exptl. Cell Res. 77, 415 (1973).

14. Stimac, E., D. Housman and J. A. Huberman: J. Mol. Biol. 115, 485 (1977).

15. Venkatesan, N.: Biochim. Biophys. Acta 478, 437 (1977).

16. Weintraub, H.: Nature 240, 449 (1972).

17. Elgin, S. C. R. and Weintraub, H.: Ann. Rev. Biochem. 44, 725 (1975).

18. Weintraub, H.: Cell 9, 419 (1976).

19. Ohtsubo, K. and M. Saito: Japan. J. Med. Sci. Biol. 23, 217 (1970).

20. Ueno, Y., M. Nakajima, K. Sakai, K. Ishii, N. Sato and N. Shimada: J. Biochem. (Tokyo) 74, 285 (1973).

21. Schindler, D.: Nature 249, 38 (1974).

22. Schindler, D., P. Grant and J. Davies: Nature 248, 535 (1974).

23. Wei, C. M. and C. S. McLaughlin: Biochem. Biophys. Res. Commun. 57, 838 (1974).
24. Mizuno, S.: Biochim. Biophys. Acta 383, 207 (1975).

25. Jimenez, A., L. Sanchez and D. Vazquez: Biochim. Biophys. Acta 383, 427 (1975).

26. Wescott, E. W. an H. D. Sisler: Phytopathology 54, 1261 (1964).

27. Colombo, B., L. Felicetti and C. Baglioni: Biochem. Biophys. Res. Commun. 18, 389 (1965).

28. Entner, N. and A. P. Grollman: J. Protozool. 20, 160 (1973).

29. Somasundaran, U. and L. Skogerson: Biochemistry 15, 4760 (1976).

30. Sigg, H. P. and H. P. Weber: Helv. chim. Acta 51, 1395 (1968).

31. Lazáry, S. and H. Staehelin: Experientia 24, 1171 (1968).

32. Lazáry, S. and H. Staehelin: Antibiotica Chemother. 15, 177 (1969).

33. Mishell, R. I. and R. W. Dutton: J. Exptl. Med. 126, 423 (1967).

34. Schimpl, A. and E. Wecker: University of Würzburg, unpublished experiments (1972).

35. Andersson, J., G. Möller and O. Sjöberg: Cell. Immunol. 4, 381 (1972).

36. Harries, A. W.: Exptl. Cell Res. 60, 341 (1970).

37. Resch, K. and E. Ferber: Eur. J. Biochem. 27, 153 (1972).

38. Dörries, R., A. Schimpl and E. Wecker: Eur. J. Immunol. 4, 230 (1974).

39. Waithe, W. J., P. Hathaway and K. Hirschhorn: Clin. exp. Immunol. 9, 903 (1971).

40. Ahern, T. and J. E. Kay: Biochim. Biophys. Acta 331, 91 (1973).

41. Sampson, J. and A. F. Borghetti: Nature New Biol. 238, 200 (1972).

42. Valentine, F. in Bloom, B. R. and P. R. Glade (eds.): In vitro Methods in Cell Mediated Immunity, p. 443, New YorkLondon, 1971, Academic Press.

43. Laemmli, U. K.: Nature 227, 680 (1970).

44. Thomas, J. O. and R. D. Kornberg: Proc. Natl. Acad: Sci. USA 72, 2626 (1975).

45. Hünig, T., A. Schimpl and E. Wecker: J. Exp. Med. 139, 754 (1974).

Address: Prof. Dr. G. R. Hartmann Institut für Biochemie Karlstr. 23 D-8000 München 2 